\title{
LOWER DOURO RIVER BASIN (PORTUGAL) WATER QUALITY - FOCUS ON TRACE ELEMENT CHANGES AND ANTHROPOGENIC SOURCES OF CONTAMINATION
}

\author{
COUTO C.M.C.M $\mathbf{M}^{1,2}$ \\ PINTO I. ${ }^{1,2}$ \\ MADUREIRA T.V..$^{1,3,4}$ \\ ROCHA M.J. ${ }^{1,3}$ \\ TIRITAN M.E. ${ }^{1,4}$ \\ LOPES J.A. ${ }^{2}$ \\ ALMEIDA A.A. ${ }^{2, *}$
}

\author{
${ }^{1}$ Health Sciences Research Center \\ Superior Institute of Health Sciences North (CICS-ISCS-N) \\ Gandra, Paredes, Portugal \\ ${ }^{2}$ REQUIMTE, Department of Chemical Sciences \\ Faculty of Pharmacy, University of Porto \\ Porto, Portugal \\ ${ }^{3}$ Interdisciplinary Centre for Marine and Environmental Research (CIIMAR) \\ Porto, Portugal \\ ${ }^{4}$ Centre of Medicinal Chemistry of Oporto University (CEQUIMED) \\ Porto, Portugal
}

Received: 21/10/2013

Accepted: $21 / 01 / 14$

Available online: $23 / 01 / 2014$

*to whom all correspondence should be addressed: e-mail:aalmeida@ff.up.pt

\section{ABSTRACT}

The Douro River lower basin water quality was studied regarding its concentration on 18 trace elements (Be, Al, Cr, Mn, Co, Ni, Cu, Zn, As, Se, Mo, Ag, Cd, Sb, Ba, Tl, Pb and U, measured by ICP-MS). Other physicochemical parameters, such as $\mathrm{pH}$, conductivity, dissolved oxygen and water temperature were also determined in situ.

To take into account the expected spatio-temporal changes and to look for anthropogenic influences on trace element levels, samples $(n=88)$ were collected at 11 sampling sites in four sampling campaigns (October 2007; January, March and July 2008), in both low and high tides, in order to evaluate spatial, seasonal and tidal changes.

A multivariate approach - principal component analysis - was used to investigate interelement correlations and the variability observed in the different data sets.

According to aquatic life limits (CCME, 2011), the quality of Douro River water was found acceptable. Except for DO, where a significant number of samples presented levels below $5.0 \mathrm{mg} \mathrm{l}^{-1}, \mathrm{Cr}(\mathrm{VI})$ (mean $\pm \mathrm{sd}$ $=3.09 \pm 1.54$; median $=2.82 \mathrm{ppb})$ and Se $(10.9 \pm 10.1 ; 7.74 \mathrm{ppb})$ all the other parameters measured fell well within acceptable limits. Occasional high levels were found for most trace elements, reflecting sporadic and local inputs. Important spatial differences in trace element levels were also found. Except for $\mathrm{Be}, \mathrm{Al}$ and $\mathrm{Mn}$, most metals tended to increase in the downstream direction. Some trace elements related with agriculture practices $(\mathrm{Zn}, \mathrm{Cu}$ and $\mathrm{Ni}$ ) were higher in samples collected on sampling sites located at the middle part of the studied area and were highly correlated, reflecting an eventual common source. Important seasonal differences in trace element levels were also observed, e.g., October samples were generally characterized by higher $\mathrm{Ni}, \mathrm{Cu}, \mathrm{Zn}$ and $\mathrm{Pb}$ levels.

Keywords: Douro River lower basin; trace elements; surface water; environmental monitoring; ICP-MS; PCA 


\section{Introduction}

Each river basin is unique, but there is enough similarity in hydrological and ecological characteristics for them to serve as widely applicable and operational landscape units for general environmental monitoring (Barrow, 1998). River basin water quality can be used as a reflection of the global environment that surrounds them, especially those located in urban estuaries. The quality of river water can play as an indicator of the pollution load on the environmental surroundings. Nevertheless even in highly polluted urban areas it is possible to maintain good water quality if there are efficient water treatment plants.

Among the main inorganic environmental pollutants usually found in estuaries, metals are of particular concern, due to their potential toxic effect and ability to bioaccumulate in aquatic ecosystems (Miller et al., 2002; Censi et al., 2006). Metals may have both beneficial and toxic effects.

Despite the economic and social importance of Douro River lower basin there are very few works on the characterization of metallic pollutants and its bioaccumulation on food chain, and none after recent jetties construction. The Douro River estuarine sediments, which include both sandy and muddy components, have been shown in few reports to be contaminated by trace metals, although concentrations depend on sediment structure and location. Mucha et al. $(2003 ; 2004 ; 2005)$ showed a clear signature of anthropogenic contamination for $\mathrm{Zn}, \mathrm{Cu}, \mathrm{Pb}$ and $\mathrm{Cr}$, with metals content indicating possible toxicity for sediment biota. The potential effect of the progressive increase of trace metals on the efficiency of the denitrification has also been studied (Magalhães et al,. 2002; 2003; 2005a; 2005b) in the Douro River lower basin.

The aim of this work was to start a comprehensive environmental study to relate river water quality to other environmental compartments (sediments and air) and to assess the global environmental situation of Oporto. Therefore, the goals of this study were (1) to characterize the Douro River lower basin water regarding its main physicochemical parameters; (2) to determine the levels of a large panel $(n=18)$ of trace elements [mostly metals; but also semi-metals (As, Sb) and non-metals (Se)] in Douro estuarine waters; (3) to evaluate possible seasonal and tidal variations in both main physicochemical parameters and trace element levels along the Douro lower basin; and (4) to assess its possible inputs (sources of contamination). A chemometric approach was used to evaluate changes observed.

\section{Experimental}

\subsection{Study area}

Douro River is the second most important river in Portugal. It travels a total of $927 \mathrm{~km}$ to flow into the Atlantic Ocean, $208 \mathrm{~km}$ being in the Portuguese territory.

Its lower basin is $22 \mathrm{~km}$ long (Figure 1). The seawater influence depends on the river flow and tidal magnitude.

The upper area is narrow and has a depth usually greater than 10 meters. In the lower area the width increases and the depth decreases (only exceptionally exceeding 10 meters in the main channel). The typical annual average flow at Crestuma/Lever dam is around $450 \mathrm{~m}^{3} \mathrm{~s}^{-1}$ (ranging from $200 \mathrm{~m}^{3} \mathrm{~s}^{-1}$ to 700 $\mathrm{m}^{3} \mathrm{~s}^{-1}$ in dry and rainy years, respectively), with a marked seasonal flow variability. It is described that the residence time of water in this lower basin is less than 2 days (INAG, 2011).

The last $8 \mathrm{~km}$ of the basin are located between the cities of Porto (north bank) and Vila Nova de Gaia (south bank), in a heavily populated region, with over 700,000 inhabitants - the Metropolitan Porto Area (MPA, which is the second most important metropolitan area of the country). This lower part of the basin receives largely untreated sewage from inhabitants of MPA and the discharges of a total of eight wastewater treatment plants (WWTP) (Azevedo et al., 2006). The two main WWTP (Sobreiras and Freixo; Figure 1) discharge a mean daily sewage flow of 54,000 and $35,900 \mathrm{~m}^{3}$ day $^{-1}$, respectively. 
At MPA, the manufacturing industries represent a significant part of the industrial structure, with a predominance of the traditional industries: clothing articles, metal products, textiles, food and beverages, non-electrical machinery, graphic arts, furniture, wood industries and electrical machinery.

Douro River mouth has recently experienced significant hydromorphological changes due to the construction of jetties, completed in 2008, to improve the navigational capabilities of its entrance and to provide protection to the Oporto city, often flooded by the North Atlantic Sea (Bettencourt et al., 2009).

\subsection{Samples collection}

Four sampling campaigns were conducted during the period between October 2007 and July 2008, in order to characterize the four seasons. The four seasons studied were dryer than normal. Precipitation values were $28.1 \mathrm{~mm}$ during October 2007 (lower than the mean value of $120 \mathrm{~mm}$ for this month), 141.3 during January, $68.8 \mathrm{~mm}$ during March (quite low when compared to a mean value of $117 \mathrm{~mm}$ ), and 9.4 during July (also dryer than usual) (SNIRH, 2011). Standard water analysis methods (Clesceri et al., 1999) were used to collect the samples. River water (ca. $1 \mathrm{~m}$ depth from water surface) was collected using a peristaltic pump (Global Water, model WS3000, Gold River, CA, USA) at high and low tides, on 11 sampling sites (Figure 1). A total of 88 samples (11 sampling sites $\times 2$ tides $\times 4$ seasons) were therefore collected. Sampling sites (SS) were chosen according to three main criteria: i) proximity to main WWTP - SS2, SS6 and SS10; ii) eight sampling sites were selected in the middle and upper part of the river using geographical considerations and taking into account the activities developed in the lower basin (SS3-SS5 and SS7-SS11); and iii) sampling sites SS1 and SS2 were selected to include the area near the mouth of the river.

The samples were collected into polyethylene containers, preserved by acidification with nitric acid $(\mathrm{pH}<2)$ and stored frozen until analysis.

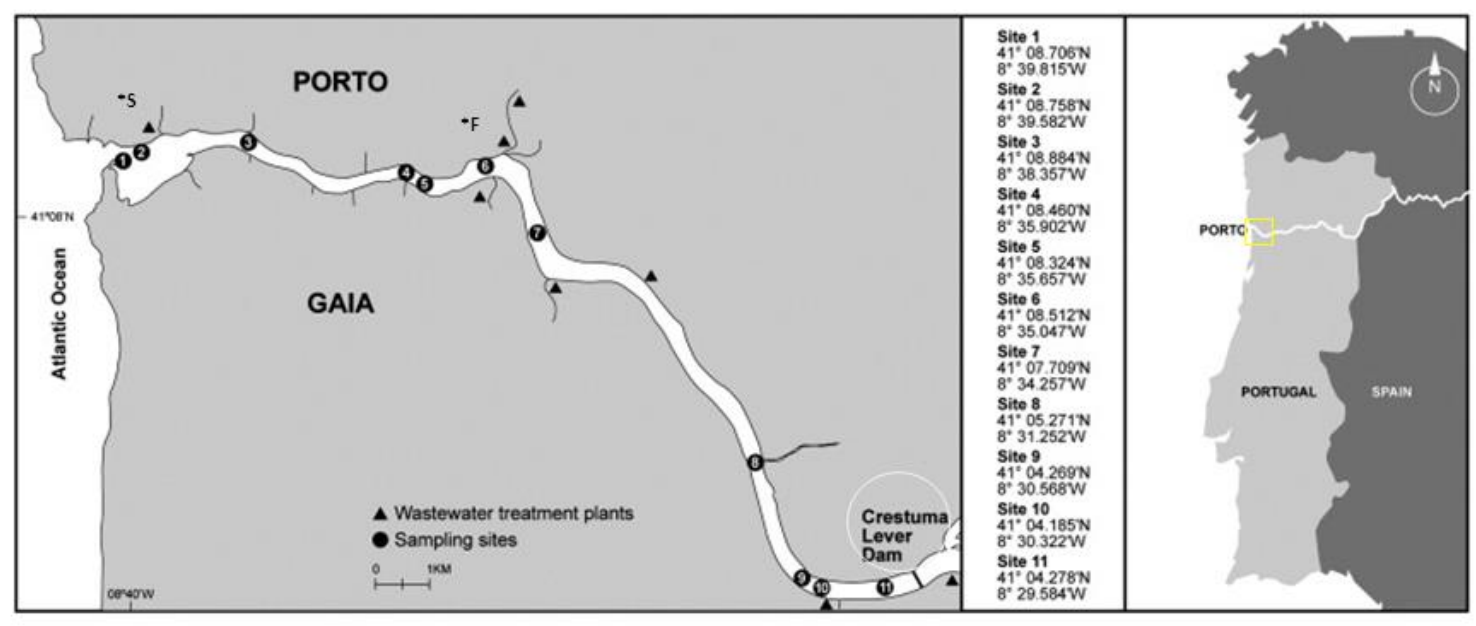

Figure 1. Location of the sampling sites (SS) in the Douro River lower basin. Distance from the river mouth: SS1 - $0.75 \mathrm{~km}$; SS2 - $1.1 \mathrm{~km}$; SS3 - $2.8 \mathrm{~km}$; SS4 - 6.2 km; SS5 - $7.0 \mathrm{~km}$; SS6 - 8.0 km; SS7 - 10.6 km; SS8 - 17.9 km; SS9 - 19.6 km; SS10 - 20.9 km; SS11 - $21.5 \mathrm{~km}$ (*S - Sobreiras WWTP; *F - Freixo WWTP).

\subsection{Physicochemical analysis}

Basic physicochemical characterization of the water samples was performed by determining $\mathrm{pH}$, dissolved oxygen (DO), temperature, salinity and conductivity. All these parameters were measured in situ using a portable Consort, model C863 multi-parameter analyser (Turnhout, Belgium).

\subsection{Trace element analysis}

Trace element analysis was performed using a VG Elemental (Winsford, UK), PlasmaQuad 3 ICP-MS, equipped with a Meinhard type A pneumatic concentric nebulizer, a quartz water cooled impact bead spray chamber, a standard quartz tube torch and nickel sample and skimmer cones. Both the spray 
chamber and sampling interface were cooled to $10 \stackrel{\circ}{ } \mathrm{C}$ by circulating water. Argon of $99.9999 \%$ purity (Alphagaz $2^{\mathrm{TM}}$, supplied by Air Liquide, Maia, Portugal) was used as the plasmogenic gas. A Gilson (Villier le Bel, France), model Minipuls 3 peristaltic pump was used for sample introduction. The main operating conditions for ICP-MS determinations are indicated in Table 1. Analytical procedure used was based on the U.S. Environmental Protection Agency (EPA) Method 200.8 "Determination of trace elements in waters and wastes by inductively coupled plasma - mass spectrometry" (Creed et al., 1994). The elemental isotopes (m/z ratios) ${ }^{9} \mathrm{Be},{ }^{27} \mathrm{Al},{ }^{51} \mathrm{~V},{ }^{52} \mathrm{Cr},{ }^{55} \mathrm{Mn},{ }^{59} \mathrm{Co},{ }^{60} \mathrm{Ni},{ }^{65} \mathrm{Cu},{ }^{66} \mathrm{Zn},{ }^{75} \mathrm{As},{ }^{82} \mathrm{Se},{ }^{95} \mathrm{Mo},{ }^{107} \mathrm{Ag}$, ${ }^{111} \mathrm{Cd},{ }^{121} \mathrm{Sb},{ }^{137} \mathrm{Ba},{ }^{205} \mathrm{Tl},{ }^{208} \mathrm{~Pb},{ }^{232} \mathrm{Th},{ }^{238} \mathrm{U}$ (as analytical masses) and ${ }^{45} \mathrm{Sc},{ }^{89} \mathrm{Y},{ }^{115} \mathrm{In},{ }^{159} \mathrm{~Tb}$ and ${ }^{209} \mathrm{Bi}$ (as internal standards) were monitored. ${ }^{83} \mathrm{Kr}$ and ${ }^{77} \mathrm{ArCl}$ were also monitored to correct for instrumental isobaric interferences. The instrument was tuned for maximum signal sensitivity and stability using ${ }^{115}$ In as the target isotope. All samples were analyzed twice (two determinations in the same analytical run) after a single 1+1 dilution with internal standard solution ( $40 \mathrm{ppb}$ of $\mathrm{Sc}, \mathrm{Y}, \mathrm{In}, \mathrm{Tb}$ and $\mathrm{Bi}$ ). Instrumental limits of detection (LOD) were calculated as the concentration corresponding to 3 times the standard deviation of 10 repeated determinations of the calibration blank signal. Results for Th were not considered because significant memory effects were observed and most samples presented concentration near or below the LOD, estimated as $0.090 \mathrm{ppb}$. Results for $\mathrm{V}$ were also only considered for sampling points SS8-SS11, because due to salinity, values obtained for other SS were too high, reflecting some isobaric interference $\left({ }^{35} \mathrm{Cl}^{16} \mathrm{O}^{+}\right)$on the target analyte $\left({ }^{51} \mathrm{~V}\right)$ and were considered as not accurate.

\subsubsection{Reagents and standards}

Ultrapure water (resistivity $>18 \mathrm{M} \Omega . \mathrm{cm}, 25^{\circ} \mathrm{C}$ ) produced with a Milli-Q RG Ultrapure Water Purification System (Billerica, MA, USA) and decontaminated plastic labware (by immersion in diluted nitric acid during at least $24 \mathrm{~h}$ and thorough washing with ultrapure water) was always used.

Nitric acid solutions were prepared by dilution of concentrated $(65 \% \mathrm{w} / \mathrm{v})$ TraceSELECT ${ }^{\circ}$ Ultra nitric acid (Fluka, Buchs, Switzerland) with ultrapure water. Solutions for ICP-MS analysis (calibration standards, internal standard solution, tuning solution) were prepared from commercial solutions available from AccuStandard (New Haven, CT, USA): ICP-MS-200.8-CAL1R-1 (18 elements; $10 \mathrm{mg} \mathrm{I}^{-1}$, except Se - $50 \mathrm{mg} \mathrm{I}^{-}$ ${ }^{1}$ ), ICP-MS-200.8-CAL2-1 (Ag and Ba, $10 \mathrm{mg} \mathrm{I}^{-1}$ ), ICP-MS-200.8-IS-1 (Internal Standard solution; Bi, In, Sc, $\mathrm{Tb}$ and $\mathrm{Y}, 100 \mathrm{mg} \mathrm{l}^{-1}$ ) and ICP-MS-200.8-TUN-1 (Tuning solution; Be, Co, In, Mg and Pb, $10 \mathrm{mg} \mathrm{l}^{-1}$ ).

\subsubsection{Certified reference materials}

Three certified reference materials were used to evaluate the accuracy of the analytical procedure: 1 ) ERM CA010a, sample 106; 2) ERM CA021a, sample 036, and 3) Analytical Reference Material TM-24.2, from National Water Research Institute, Environment Canada (Burlington, Ontario, Canada). Results are presented in Table 1 and show acceptable analytical accuracy.

\subsection{Statistical data analysis}

Descriptive statistics (mean, median, standard deviation, etc.) and mean comparison (t-test and oneway ANOVA) were calculated using Microsoft Excel for Windows data analysis tool. MATLAB version 6.5 software package (The Mathworks, Natick, USA) supported the entire chemometric data analysis, from data importing to visualization, multivariate analysis (Principal Component Analysis) and output artwork production.

Environmental sciences deal with systems characterized by inherent variability (natural, anthropogenic, spatial and temporal), with multivariate origin. Therefore, the revealing of relations, their limits and hierarchy should be a principal goal in the analysis of environmental systems. Principal Component Analysis (PCA) is a mainstream approach of modern data analysis. It is a traditional multivariate statistical method commonly used to reduce the number of predictive variables and solve the multicollinearity problem aiming to get a few linear combinations of the variables that can be used to summarize the data without losing too much information in the process. 
Table 1. ICP-MS main operating conditions, limits of detection and analytical accuracy (results from the analysis of certified reference materials).

\begin{tabular}{|c|c|c|c|c|c|c|c|}
\hline \multicolumn{2}{|c|}{ Instrumental } & \multicolumn{2}{|c|}{ Setup for survey run } & \multicolumn{2}{|c|}{ Setup for main run } & \multicolumn{2}{|c|}{ Setup of the ICP } \\
\hline Detector & Sequential & Sweeps & 20 & Acquisition Mode & Peak Jumping & Cool gas flow rate & $131 \mathrm{~min}^{-1}$ \\
\hline Detection Mode & Pulse Counting & Dwell time & 300 & Sweeps & 100 & Auxiliary gas flow rate & $0.901 \mathrm{~min}^{-1}$ \\
\hline Acquisition Mode & Continuous & Channels per mass & 10 & Dwell time & 10 & Nebulizer gas flow rate & $0.821 \mathrm{~min}^{-1}$ \\
\hline \multirow[t]{4}{*}{ Prescan } & No & Acquisition time & $14 \mathrm{~s}$ & Channels per mass & 3 & RF forward power & $1350 \mathrm{~W}$ \\
\hline & & & & Acquisition time & 96 & & \\
\hline & & & & Channel Spacing & 0.02 & & \\
\hline & & & & Replicates & 2 & & \\
\hline
\end{tabular}

\begin{tabular}{|c|c|c|c|c|c|c|c|c|c|c|c|c|c|c|c|c|c|c|c|}
\hline & & $\mathrm{Be}$ & Al & $\mathrm{Cr}$ & $\mathrm{Mn}$ & Co & $\mathrm{Ni}$ & $\mathrm{Cu}$ & $\mathrm{Zn}$ & As & $\mathrm{Se}$ & Mo & $\mathrm{Ag}$ & $\mathrm{Cd}$ & $\mathrm{Sb}$ & $\mathrm{Ba}$ & $\mathrm{Tl}$ & $\mathrm{Pb}$ & U \\
\hline \multicolumn{2}{|c|}{$\begin{array}{l}\text { Limit of Detection } \\
\text { (LOD) }\end{array}$} & 0.009 & 0.729 & 0.084 & 0.012 & 0.009 & 0.393 & 0.054 & 0.276 & 0.840 & 3.05 & 0.030 & 0.066 & 0.012 & 0.009 & 0.048 & 0.003 & 0.012 & 0.006 \\
\hline \multirow{2}{*}{$\begin{array}{c}\text { ERM } \\
\text { CA021 } \\
\text { a }\end{array}$} & Obtained & -- & 218.9 & 46.7 & 51.6 & -- & 18.9 & 2062 & 559 & 8.45 & 5.41 & -- & 6.49 & 4.19 & 6.19 & 108.1 & -- & 24.9 & -- \\
\hline & Certified & -- & $193 \pm 6$ & $45.3 \pm 2.6$ & $48.2 \pm 1.2$ & -- & $18.3 \pm 0.9$ & $1975 \pm 54$ & $514 \pm 9$ & $9.9 \pm 0.5$ & $9.5 \pm 0.6$ & -- & $7.6 \pm 0.5$ & $4.4 \pm 0.2$ & $4.9 \pm 0.3$ & $101 \pm 4$ & -- & $23.7 \pm .2$ & -- \\
\hline \multirow{2}{*}{$\begin{array}{c}\text { ERM } \\
\text { CA010 } \\
\text { a } \\
\end{array}$} & Obtained & -- & 199.8 & 41.8 & 48.4 & -- & 45.4 & -- & 537 & 48.3 & 11.4 & -- & -- & -- & 13.7 & 116.9 & -- & 95.2 & -- \\
\hline & Certified & -- & $208 \pm 19$ & $48 \pm 3$ & $48 \pm 2$ & -- & $48 \pm 4$ & -- & $542 \pm 16$ & $55 \pm 5$ & $9.5 \pm 0.8$ & -- & -- & -- & $11.9 \pm 1.2$ & $116 \pm 4$ & -- & $95 \pm 3$ & -- \\
\hline \multirow{2}{*}{$\begin{array}{l}\mathrm{TM}- \\
24.2\end{array}$} & Obtained & 2.35 & 29.5 & 4.43 & 8.25 & 6.21 & 4.32 & 7.58 & 20.2 & 4.49 & 3.65 & 4.58 & 2.52 & 3.92 & 3.05 & 9.08 & 3.90 & 5.98 & 4.52 \\
\hline & Certified & $2.0 \pm 0.27$ & $30.6 \pm 7.5$ & $4.6 \pm 1.0$ & $8.4 \pm 1.3$ & $5.9 \pm 1.0$ & $5.0 \pm 1.6$ & $7.3 \pm 1.7$ & $20 \pm 4.7$ & $4.9 \pm 1.0$ & $3.2 \pm 0.82$ & $5.6 \pm 1.0$ & [2.6] & $4.1 \pm 0.49$ & $2.5 \pm 0.58$ & $8.7 \pm 1.3$ & $3.8 \pm 0.52$ & $6.1 \pm 1.2$ & $4.4 \pm 0.55$ \\
\hline
\end{tabular}

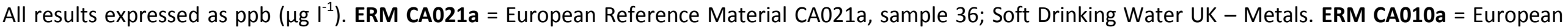

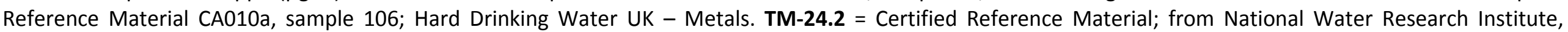

Canada. 


\section{Results and Discussion}

\subsection{Physicochemical parameters}

Results for the main physicochemical parameters of water samples are given in Table 2. Conductivity values show an influence from seawater from sampling site SS1 to sampling site SS7.

A significant decrease in conductivity and salinity (data not shown) were observed in accordance to distance to the river mouth. Conductivities lower than $1 \mathrm{mS} \mathrm{cm}^{-1}$ and salinities lower than $1 \%$ were observed for SS8-SS11, reflecting the natural river composition (Figure 2a). Due to seawater influence, conductivity was higher at HT. Mean values were higher in October and lower in March, and quite similar in January and July, which may reflect the influence of precipitation on river flow (Figure 2a).

Mean $\mathrm{pH}$ value for the 88 water samples was $7.74 \pm 0.37$. From SS1 to SS7, due to seawater influence, $\mathrm{pH}$ values tend to be higher at $\mathrm{HT}(7.78 \pm 0.33)$ than at $\mathrm{LT}(7.60 \pm 0.48)$ with Canadian Environmental Quality guidelines recommended water quality criterion for protection of fresh water aquatic life $(6.5-9)$ never being exceeded (CCME, 2011). Significant seasonal differences were found. $\mathrm{pH}$ values were significantly different, the higher difference being between July $(8.12 \pm 0.23)$ and January $(7.41 \pm 0.25)(P<0.0001)$ (Figure $2 \mathrm{~b}$ ), probably due to increased surface runoff during raining seasons.

Water temperature was significantly higher in July/October than in March/January (Figure 2c). Mean water temperature values tended to be higher in HT than LT (18.4 \pm 6.7 and $16.6 \pm 5.6$ 으, respectively), but the difference was not statistically significant $(P=0.1751)$. This is a result of environmental and seawater temperature influences. It must be noted that, except for March, all sample collections were performed during the morning for LT and in the afternoon for $\mathrm{HT}$.

Mean values for DO were significantly different $(P<0,0001)$ at the four sampling collections, higher in March and July and lower in January and October (Figure 2d). The dissolved oxygen content of natural waters depends on a complex interaction of several factors: atmospheric pressure, temperature, salinity, turbulence and photosynthetic activity of algae and plants in the water body. Regarding temperature, the colder the water the more oxygen can be dissolved. In our study, colder water temperatures were observed in January and March, and higher DO was observed in March, which is in accordance to the expected trend). However, since DO values were quite lower than the oxygen saturation level in water, other factors must be involved, strongly influencing the DO levels found. One is probably an increased demand of oxygen in the system observed in October, since Autumn leaf fall, in combination with low flow (during dry seasons, water levels decrease, the flow rate of a river slows down and water mixes less with the air), has been shown to create seasonally low oxygen concentrations. In January we may still have an increased demand of oxygen together with a decreased photosynthetic activity (and a decreased photosynthetic activity results in decreased DO). The high DO values found in July (despite the warmer temperatures) can be explained by the intense sunlight and intense photosynthesis of aquatic biota.

A significant number of samples (55.7\%) presented DO levels below $5.0 \mathrm{mg} \mathrm{l}^{-1}$, a value widely assumed as the limit where aquatic life is put under stress. The lowest mean values were found at sampling sites SS2, SS6, SS8 and SS10. All these sites are located near WWTP or at the confluence of a highly polluted tributary (Sousa River) (SS8).

\subsection{Trace element levels}

The results for the set of 18 elements determined in Douro River water samples are summarized in Table 3. For comparison purposes, results published for other European rivers (Guadalquivir - due to geographical proximity - and Vistula - due to its known high trace metals contamination) are presented. The mean values for each metal at each site were compared with values for aquatic life limits according to Water Quality for the Protection of Aquatic Life from the Canadian Environmental Quality Guidelines (CCME, 2011). In the situations where a high percentage of the results obtained were below LOD those values were replaced by value $L O D / 2$.

The following are some highlights of the results obtained. 
Table 2. Results for the main physicochemical parameters in Douro River lower basin water samples collected at the 11 sampling sites, in the four seasons and in both low and high tide $(n=88)$.

\begin{tabular}{|c|c|c|c|c|c|c|c|c|c|c|c|c|c|c|c|c|c|c|c|c|c|c|c|c|c|c|c|c|c|c|c|c|}
\hline \multirow{3}{*}{ SS } & \multicolumn{8}{|c|}{$\mathrm{pH}$} & \multicolumn{8}{|c|}{ Temperature $\left({ }^{\circ} \mathrm{C}\right)$} & \multicolumn{8}{|c|}{$\mathrm{DO}\left(\mathrm{mg} \mathrm{l}^{-1}\right)$} & \multicolumn{8}{|c|}{ Conductivity ( $\mathrm{mS} \mathrm{cm}^{-1}$ ) } \\
\hline & \multicolumn{2}{|c|}{ Oct } & \multicolumn{2}{|c|}{ Jan } & \multicolumn{2}{|c|}{ Mar } & \multicolumn{2}{|c|}{ Jul } & \multicolumn{2}{|c|}{ Oct } & \multicolumn{2}{|c|}{ Jan } & \multicolumn{2}{|c|}{ Mar } & \multicolumn{2}{|c|}{ Jul } & \multicolumn{2}{|c|}{ Oct } & \multicolumn{2}{|c|}{ Jan } & \multicolumn{2}{|c|}{ Mar } & \multicolumn{2}{|c|}{ Jul } & \multicolumn{2}{|c|}{ Oct } & \multicolumn{2}{|c|}{ Jan } & \multicolumn{2}{|c|}{ Mar } & \multicolumn{2}{|c|}{ Jul } \\
\hline & LT & HT & LT & HT & LT & HT & LT & HT & LT & HT & LT & HT & LT & HT & LT & HT & LT & HT & LT & $\mathrm{HT}$ & LT & HT & LT & HT & LT & HT & LT & HT & LT & HT & LT & HT \\
\hline 1 & 7.62 & 7.94 & 7.07 & 7.72 & 7.46 & 7.74 & 8.46 & 8.40 & 16 & 27 & 10 & 14 & 14 & 12 & 21 & 21 & 3.20 & 3.30 & 3.81 & 3.30 & 6.05 & 6.02 & 5.52 & 6.42 & 20.4 & 39.1 & 13.1 & 43.5 & 13.8 & 16.3 & 19.4 & 39.4 \\
\hline 2 & 7.07 & 7.10 & 6.89 & 7.68 & 7.89 & 7.95 & 8.30 & 8.30 & 18 & 28 & 10 & 14 & 14 & 12 & 23 & 22 & 3.30 & 2.70 & 4.09 & 3.31 & 5.89 & 6.06 & 5.31 & 6.68 & 19.8 & 27.1 & 13.6 & 28.0 & 14.8 & 17.0 & 14.0 & 29.5 \\
\hline 3 & 6.89 & 7.32 & 7.28 & 7.43 & 7.75 & 8.06 & 8.18 & 8.21 & 18 & 25 & 9 & 13 & 14 & 12 & 22 & 23 & 3.00 & 2.80 & 4.14 & 3.29 & 6.51 & 6.83 & 5.41 & 5.87 & 9.56 & 22.7 & 7.54 & 15.2 & 10.5 & 8.76 & 10.8 & 15.2 \\
\hline 4 & 7.19 & 7.28 & 7.12 & 7.37 & 7.93 & 8.00 & 8.21 & 8.10 & 18 & 24 & 10 & 14 & 13 & 12 & 23 & 26 & 3.30 & 2.85 & 4.11 & 3.37 & 8.41 & 7.02 & 4.92 & 6.05 & 4.06 & 19.0 & 3.70 & 13.6 & 5.79 & 8.36 & 5.14 & \begin{tabular}{|l|l} 
& 11.7
\end{tabular} \\
\hline 5 & 7.28 & 7.64 & 7.13 & 7.48 & 7.95 & 7.99 & 8.11 & 8.03 & 18 & 26 & 9 & 13 & 13 & 12 & 23 & 26 & 3.00 & 2.80 & 4.16 & 3.32 & 6.69 & 7.84 & 5.30 & 6.25 & 4.14 & 12.0 & 3.09 & 8.13 & 4.81 & 4.81 & 5.32 & 6.49 \\
\hline 6 & 7.31 & 7.43 & 7.18 & 7.51 & 7.78 & 7.92 & 8.13 & 8.06 & 19 & 25 & 9 & 12 & 13 & 12 & 23 & 27 & 3.20 & 2.99 & 4.06 & 3.23 & 6.27 & 6.70 & 5.20 & 5.74 & 3.78 & 10.4 & 1.20 & 7.33 & 4.27 & 4.43 & 4.61 & 5.09 \\
\hline 7 & 7.30 & 7.65 & 7.17 & 7.68 & 7.99 & 8.01 & 8.10 & 8.02 & 20 & 24 & 10 & 12 & 14 & 12 & 25 & 26 & 2.90 & 3.15 & 4.10 & 3.46 & 6.78 & 6.64 & 5.62 & 5.32 & 3.32 & 3.73 & 0.41 & 3.92 & 2.47 & 3.48 & 2.84 & 2.96 \\
\hline 8 & 7.64 & 7.88 & 7.31 & 7.40 & 7.75 & 7.63 & 8.11 & 7.86 & 20 & 24 & 10 & 11 & 14 & 9 & 24 & 26 & 3.20 & 2.83 & 3.96 & 3.58 & 6.43 & 6.80 & 4.28 & 5.99 & 0.34 & 0.33 & 0.28 & 0.17 & 0.32 & 0.63 & 0.40 & 1.40 \\
\hline 9 & 7.73 & 7.73 & 7.44 & 7.61 & 7.88 & 8.05 & 8.64 & 7.96 & 21 & 21 & 11 & 11 & 14 & 9 & 26 & 26 & 3.10 & 3.40 & 3.57 & 3.32 & 7.25 & 6.70 & 4.05 & 6.80 & 0.37 & 0.24 & 0.16 & 0.16 & 0.30 & 0.80 & 0.38 & 0.82 \\
\hline 10 & 7.70 & 7.98 & 7.42 & 7.89 & 7.98 & 8.12 & 7.60 & 7.98 & 21 & 20 & 10 & 10 & 14 & 13 & 26 & 26 & 3.00 & 3.40 & 3.45 & 3.62 & 6.31 & 7.18 & 4.15 & 4.42 & 0.36 & 0.23 & 0.16 & 0.17 & 0.25 & 0.55 & 0.44 & 1.39 \\
\hline 11 & 7.75 & 7.83 & 7.66 & 7.59 & 7.95 & 8.16 & 7.84 & 7.93 & 23 & 23 & 10 & 11 & 14 & 12 & 26 & 26 & 2.90 & 3.30 & 3.48 & 3.37 & 7.20 & 6.50 & 5.16 & 5.63 & 0.27 & 0.24 & 0.16 & 0.16 & 0.27 & 0.65 & $\mid 0.56$ & 1.09 \\
\hline
\end{tabular}

Sampling schedule: October 10th (LT / HT): SS1 - 9:15 / 15:19; SS2 - 9:25 / 15:30; SS3 - 9:45 / 15:52; SS4 - 10:00 / 16:04; SS5 - 10:15 / 16:10; SS6 - 10:30 / 16:23; SS7 - 10:49 / 16:36; SS8 - 11:20 / 16:54; SS9 - 11:38 / 17:10; SS10 - 11:49 / 17:21; SS11 - 12:03 / 17:32. Note: In the other months, the sampling schedule was similar, starting at January 22th - 9:00 / 15:00 (LT / HT); March 17th - 18:30 / 12:30 (LT / HT) and July 17th - 8:30 / 14:30. 
Table 3. Results (ppb) for the trace element analysis of Douro River lower basin water samples collected at the 11 sampling sites, in the four seasons and in both low and high tide $(n=88)$.

\begin{tabular}{|c|c|c|c|c|c|}
\hline \multirow[b]{2}{*}{ Element } & \multicolumn{2}{|c|}{ Douro River } & \multirow{2}{*}{$\begin{array}{c}\text { Guadalquivir }^{\#} \\
\text { Range }\end{array}$} & \multirow{2}{*}{$\begin{array}{c}\text { Vistula }^{\$} \\
\text { Range }\end{array}$} & \multirow[t]{2}{*}{$\begin{array}{l}\text { Aquatic Life limit } \\
\text { (CCME 2011) }\end{array}$} \\
\hline & $\begin{array}{l}\text { Mean } \pm s d \\
\text { (median) }\end{array}$ & Range* & & & \\
\hline $\mathrm{Be}$ & $\begin{array}{c}0.025 \pm 0.007 \\
(0.027)\end{array}$ & $\begin{array}{c}<0.009 \\
(n=28)- \\
0.126\end{array}$ & -- & -- & \\
\hline Al & $\begin{array}{c}83.4 \pm 32.4 \\
(78.6)\end{array}$ & $23.7-201.1$ & -- & -- & 100 \\
\hline $\mathrm{Cr}$ & $\begin{array}{c}3.09 \pm 1.54 \\
(2.82)\end{array}$ & $\begin{array}{c}<0.084(n=1) \\
-9.05\end{array}$ & -- & -- & 1 \\
\hline $\mathrm{Mn}$ & $\begin{array}{c}16.3 \pm 5.89 \\
(15.3)\end{array}$ & $3.98-49.1$ & $<1-135$ & $5.3-584$ & \\
\hline Co & $\begin{array}{c}0.44 \pm 0.25 \\
(0.37)\end{array}$ & $0.119-1.26$ & $0.008-0.8$ & $0.51-0.73$ & \\
\hline $\mathrm{Ni}$ & $\begin{array}{c}5.51 \pm 2.48 \\
(5.66)\end{array}$ & $\begin{array}{c}<0.393 \\
(n=14)-46.7\end{array}$ & $<0.02-4.6$ & -- & $102^{* *}$ \\
\hline $\mathrm{Cu}$ & $\begin{array}{c}5.72 \pm 5.46 \\
(3.70)\end{array}$ & $0.365-19.8$ & $0.74-7.4$ & $0.9-90$ & $2-4$ \\
\hline $\mathrm{Zn}$ & $\begin{array}{c}7.90 \pm 8.55 \\
(6.23)\end{array}$ & $\begin{array}{c}<0.276(n=4) \\
-39.2 \\
\end{array}$ & $<0.15-7.3$ & $16.2-169$ & 30 \\
\hline As & $\begin{array}{c}4.50 \pm 2.06 \\
(4.26)\end{array}$ & $\begin{array}{c}<0.84(n=37) \\
-25.7\end{array}$ & -- & -- & 5 \\
\hline Se & $\begin{array}{c}10.9 \pm 10.1 \\
(7.74)\end{array}$ & $\begin{array}{c}<3.05(n=60) \\
-103 \\
\end{array}$ & -- & -- & 1 \\
\hline Mo & $\begin{array}{c}1.91 \pm 1.96 \\
(1.20)\end{array}$ & $0.114-8.98$ & -- & -- & 73 \\
\hline $\mathrm{Ag}$ & $\begin{array}{c}10.3 \pm 33.4 \\
(0.21)\end{array}$ & $\begin{array}{c}<0.068- \\
144.5\end{array}$ & -- & -- & 0.1 \\
\hline Cd & $\begin{array}{c}0.046 \pm 0.022 \\
(0.043)\end{array}$ & $\begin{array}{c}<0.012 \\
(n=25)- \\
0.215\end{array}$ & $0.0014-0.07$ & $0.51-0.73$ & $0.036^{* *}$ \\
\hline Sb & $\begin{array}{c}0.84 \pm 1.06 \\
(0.54)\end{array}$ & $\begin{array}{c}<0.009(n=1) \\
-8.33\end{array}$ & -- & - & \\
\hline $\mathrm{Ba}$ & $\begin{array}{c}21.7 \pm 8.26 \\
(19.6)\end{array}$ & $6.11-39.8$ & -- & -- & \\
\hline $\mathrm{TI}$ & $\begin{array}{c}0.10 \pm 0.16 \\
(0.035)\end{array}$ & $\begin{array}{c}<0.003(n=1) \\
-1.23\end{array}$ & -- & -- & 0.8 \\
\hline $\mathrm{Pb}$ & $\begin{array}{c}5.36 \pm 12.3 \\
(1.49)\end{array}$ & $0.03-93.2$ & $0.0012-3.3$ & $0.24-0.39$ & $3.6^{* *}$ \\
\hline U & $\begin{array}{c}1.29 \pm 0.63 \\
(1.16)\end{array}$ & $0.161-3.56$ & -- & -- & 15 \\
\hline
\end{tabular}

*Note: between brackets, the number of samples having lower than the LOD trace element concentration is indicated. Values lower than LOD were replaced by LOD/2).

**For maximum hardness $=110 \mathrm{mg} \mathrm{I}^{-1}$.

Aluminum mean concentration was $83.4 \pm 32.4 \mathrm{ppb}$, and levels tend to be quite constant with some sporadic high levels, reflecting occasional discharges (anthropogenic origin) (Figure 3Al). Values were significantly higher at SS8, the mouth of Sousa River, a highly industrial-polluted tributary of Douro River, where an industrial origin is probably the main source of metals in water. Higher values were also found at SS4 and SS2. The proximity of WWTP, where aluminum sulfate is commonly used as primary 
coagulant might explain these values (the highest Al value found - $201 \mathrm{ppb}$ - was obtained at SS2, were WWTP effluent is discharged into Douro river).
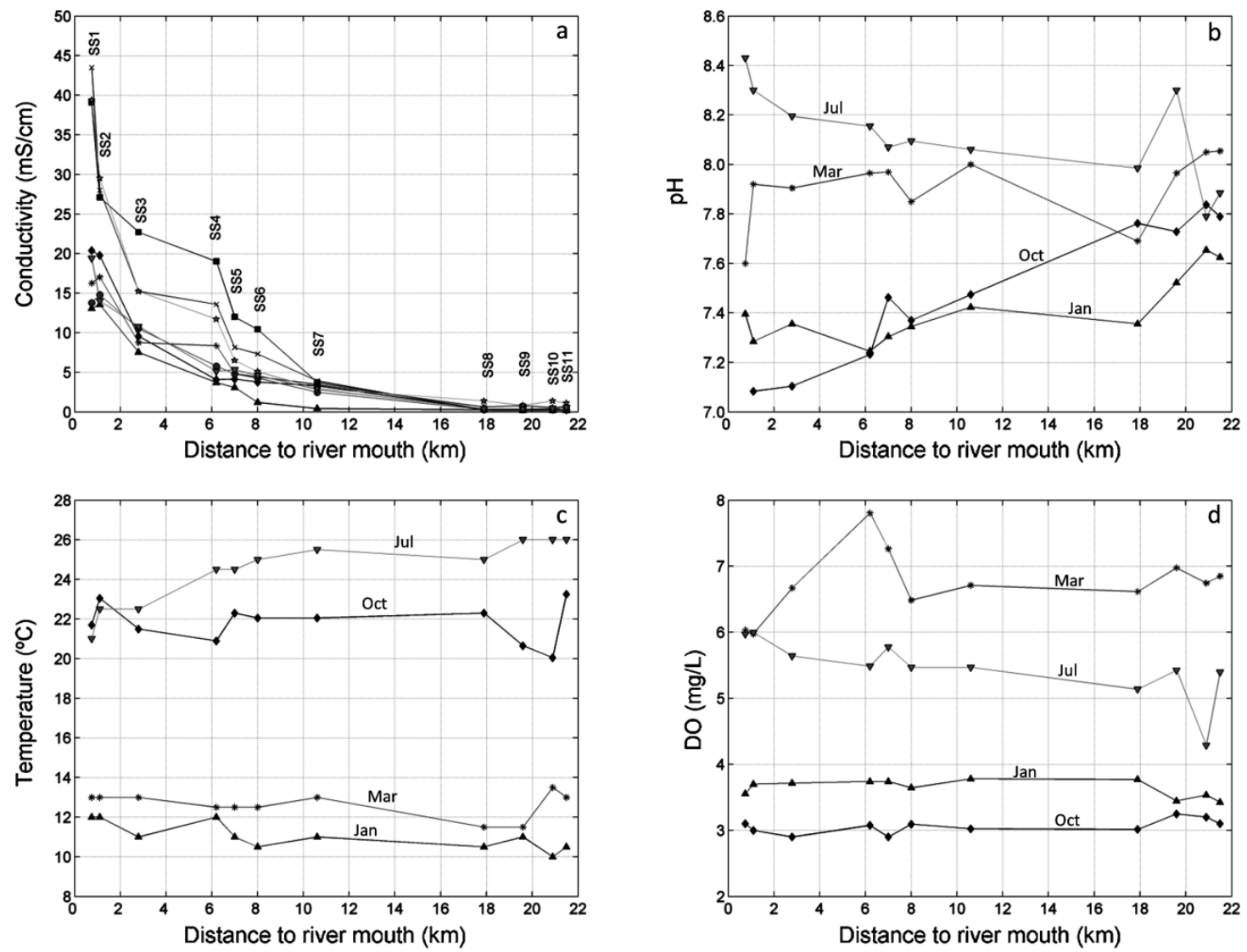

Figure 2 - (a) Conductivity values at the different 11 sampling sites in the four sampling seasons (October, January, July and March) at both tides (low tide and high tide). Legend: $\bullet$ October LT;

October HT; $\boldsymbol{\Delta}$ January LT; $\times$ January HT; $*$ March LT; $\bigcirc$ March HT; $\boldsymbol{\nabla}$ July LT; $\star$ July HT.

(b-d) Mean values for $\mathrm{pH}(\mathrm{b})$, temperature (c) and DO (d) at the different 11 sampling sites in the four sampling seasons (October, January, July and March).

Chromium mean concentration, considered as $\mathrm{Cr}(\mathrm{VI})$, the most toxic $\mathrm{Cr}$ species (Group 1, according to IARC's classification) (IARC, 2011) was significantly higher than data presented as aquatic life limit (CCME ,2011). This probably reflects industrial sources of contamination (concentrations of $5-20 \mathrm{ppb}$ in the Rhine River, and 10-40 ppb in the Elbe River are described) (Lenntech, 2011), since $\mathrm{Cr}$ is widely used as an alloying and plating element on metal and plastic substrates for corrosion resistance, as pigment and metal finishing (Callender, 2003; Cornelis et al., 2005). Cr mean levels at the different sampling sites showed some kind of association with WWTP (see Figure $3 \mathrm{Cr}$ and Figure 1), since highest $\mathrm{Cr}$ mean levels were found at SS1 and SS2 and at SS9. Interestingly, and despite the high metallic contamination of this river regarding, namely, $\mathrm{Al}$ (see above), $\mathrm{Mn}$ and $\mathrm{Co}$ (see below), $\mathrm{Cr}$ mean level was lower at SS8, the mouth of Sousa tributary.

Manganese showed a quite constant concentration level along the studied area, with a mean value of $16.3 \pm 5.9 \mathrm{ppb}$. When compared with the mean level for the other sampling sites, a significantly higher level was found at SS8 (Figure $3 \mathrm{Mn}$ ), suggesting contamination of industrial origin. As previously referred, this sampling site (SS8) corresponds to the mouth of the Sousa River (see Figure 1). On the contrary, a significantly lower level $(11.23 \pm 4.11)$ was found at SS1 (with lower values at HT), reflecting the lower seawater $\mathrm{Mn}$ concentration. 
The highest Co value was also observed at SS8 and on the same sample (January, HT) as for the highest $\mathrm{Mn}$ value (Figure $3 \mathrm{Co}$ ), reflecting a common industrial contamination source. The concomitant presence of $\mathrm{Mn}$ and $\mathrm{Co}$ at high concentrations in river water affected by sewage effluents has been reported (Mendiguchía et al., 2007).

Nickel highest values were found at SS5 (46.7 ppb), SS7 (43.4 ppb), SS9 (40.7 ppb) and SS11 (26.1 ppb) (Figure $3 \mathrm{Ni}$ ), sampling sites where agriculture is the predominant activity in the surrounding area (Figure 1), which is a finding consistent with previously published results (Mendiguchía et al., 2007). Probably due to higher occasional leaching from agricultural soils, the above referred highest values were all found in October, which corresponds to significant seasonal differences in Ni levels

Copper distribution along the studied area also suggested an agricultural origin. The highest concentrations (almost reaching $20 \mathrm{ppb}$ ) were observed in October at sampling sites in the middle and upper zone of the studied area (Figure 3Cu). Previously published studies (Mendiguchía et al., 2007; Linde et al., 2005) also reported higher values during rainy seasons, probably due to increased leaching processes of agricultural soils.

Arsenic compounds in agricultural products such as herbicides and fungicides and combustion of fossil fuels is a predominant source of environmental As pollution. $34 \%$ of samples collected exceeded aquatic life limits (CCME, 2011).

Selenium mean value exceeded in 10 times the aquatic life limit, but $68 \%$ of samples presented values below LOD.

Molybdenum mean value was $1.91 \pm 1.96 \mathrm{ppb}$. Mo concentrations presented a consistent gradual decrease from SS1 $(5.78 \pm 2.52 \mathrm{ppb})$ to SS7 $(0.88 \pm 0.25 \mathrm{ppb})$, and became approximately constant (ca. 0.5 $\mathrm{ppb}$ ) thereafter (Figure 3Mo), in a quite parallel manner to salinity/conductivity levels (Table 2 and Figure 2a). This may reflect the influence of seawater, where Mo levels are typically in the order of 10 ppb (Turekian, 1976). Mean values were higher in SS9 and SS6 than in neighborhood, reflecting some influence of WWTPs, and lower in SS8, reflecting a significantly different Sousa River water composition (Figure 3Mo).

Cadmium data obtained in this study are in-line with a trend for low $\mathrm{Cd}$ in river waters (Figure $3 \mathrm{Cd}$ ) (Nixon, 2011). About $28 \%$ of samples had Cd concentrations lower than the LOD (0.012 ppb).

Lead mean value found was $5.36 \pm 12.29 \mathrm{ppb}$ (median $=1.49 \mathrm{ppb}$ ), with no significant spatial differences. The highest values were found at SS2 in January and SS5 and SS9 in October, also suggesting some association with WWTP. Samples exceeded WHO guidelines for drinking water (WHO, 2011) in 15\% of the samples analyzed.

Uranium water levels are highly influenced by geological factors. Dissolved $U$ in river water is primarily a result of weathering processes on rocks and soils. River water concentrations of $U$ may also increase due to the application of phosphatic fertilizers to agricultural fields (Tagami and Uchida, 2009). Uranium mean value in Douro River water was $1.29 \pm 0.63 \mathrm{ppb}$. (Figure $3 \mathrm{U})$. A significantly lower value $(P=0.0003$ ) was found at SS8 $(0.55 \pm 0.28 \mathrm{ppb})$, the mouth of Sousa river, indicating that it travels through a different geological region. Thereafter (SS9 to SS11), U levels became approximately $0.9 \mathrm{ppb}$, which can be considered the natural background level of $U$ in Douro river water. This mean level of $U$ in Douro River water should be regarded as non-critical according to current water quality guidelines for the protection of aquatic life (long-term exposure: 15 ppb) (CCME, 2011). 

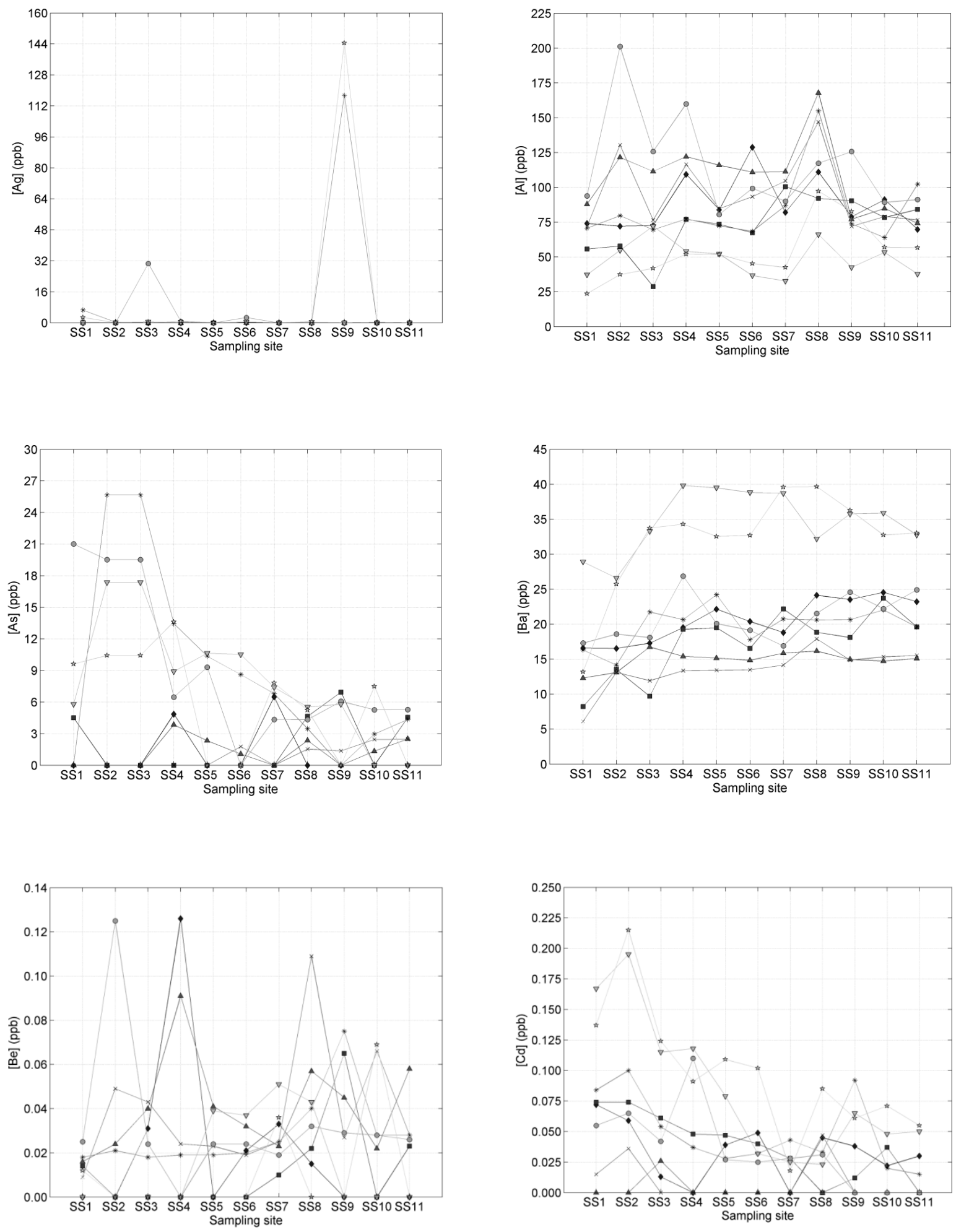

(a) 

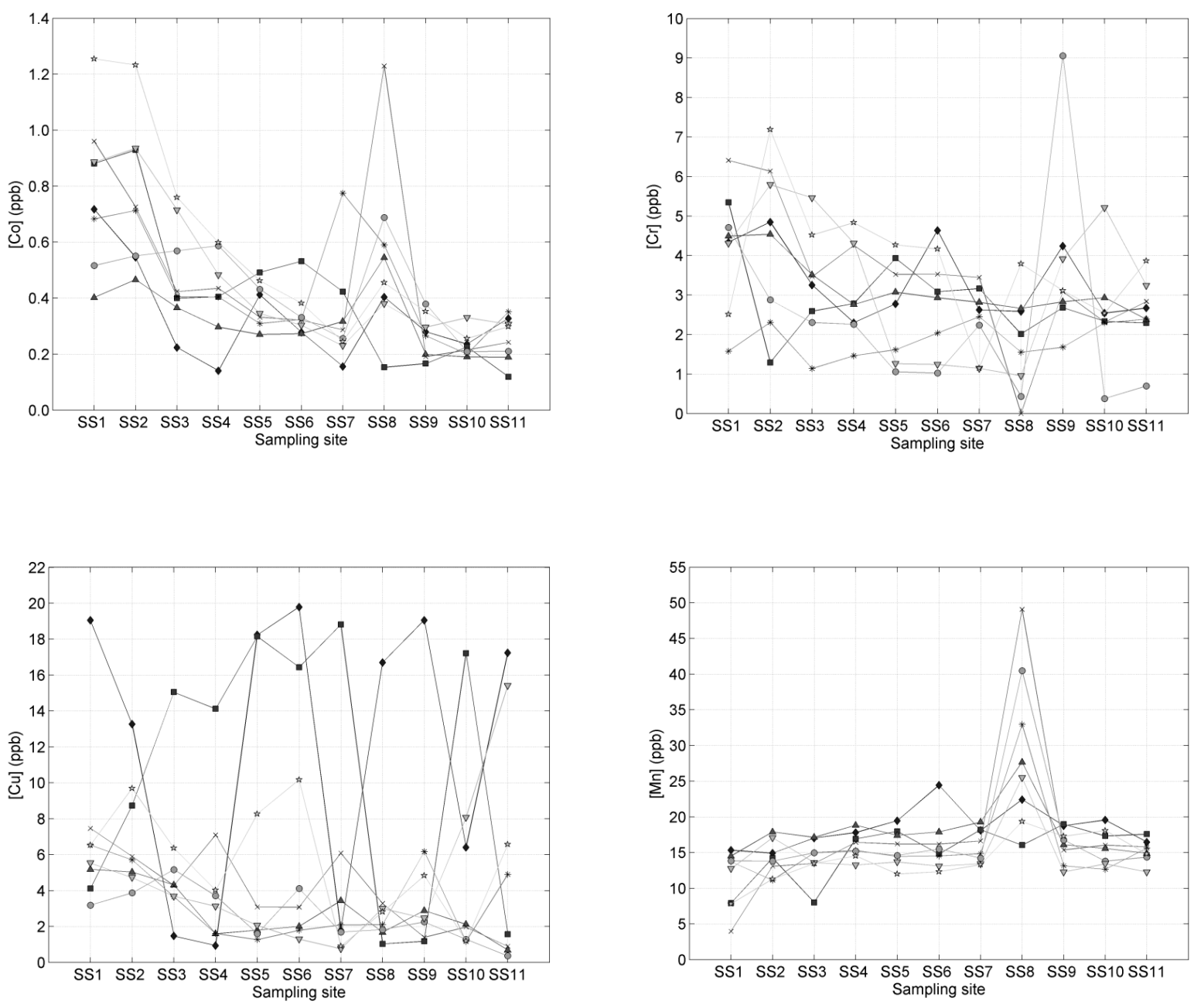

Sampling site
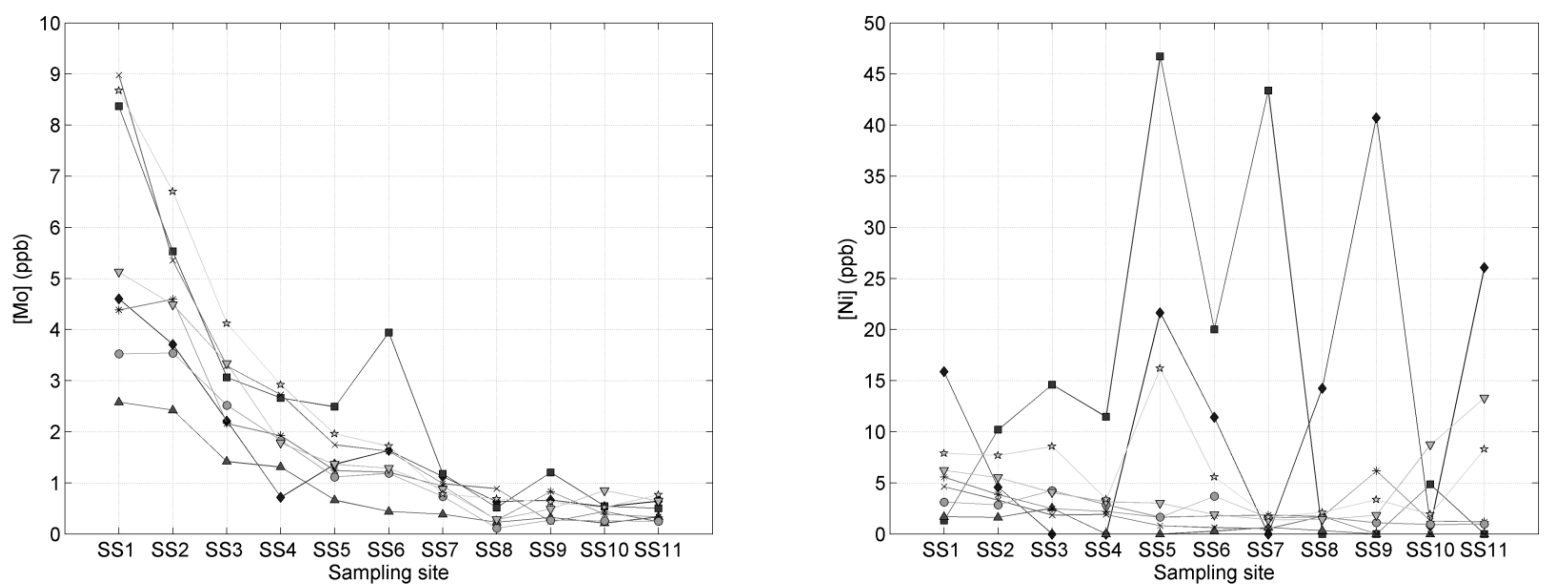

(b) 

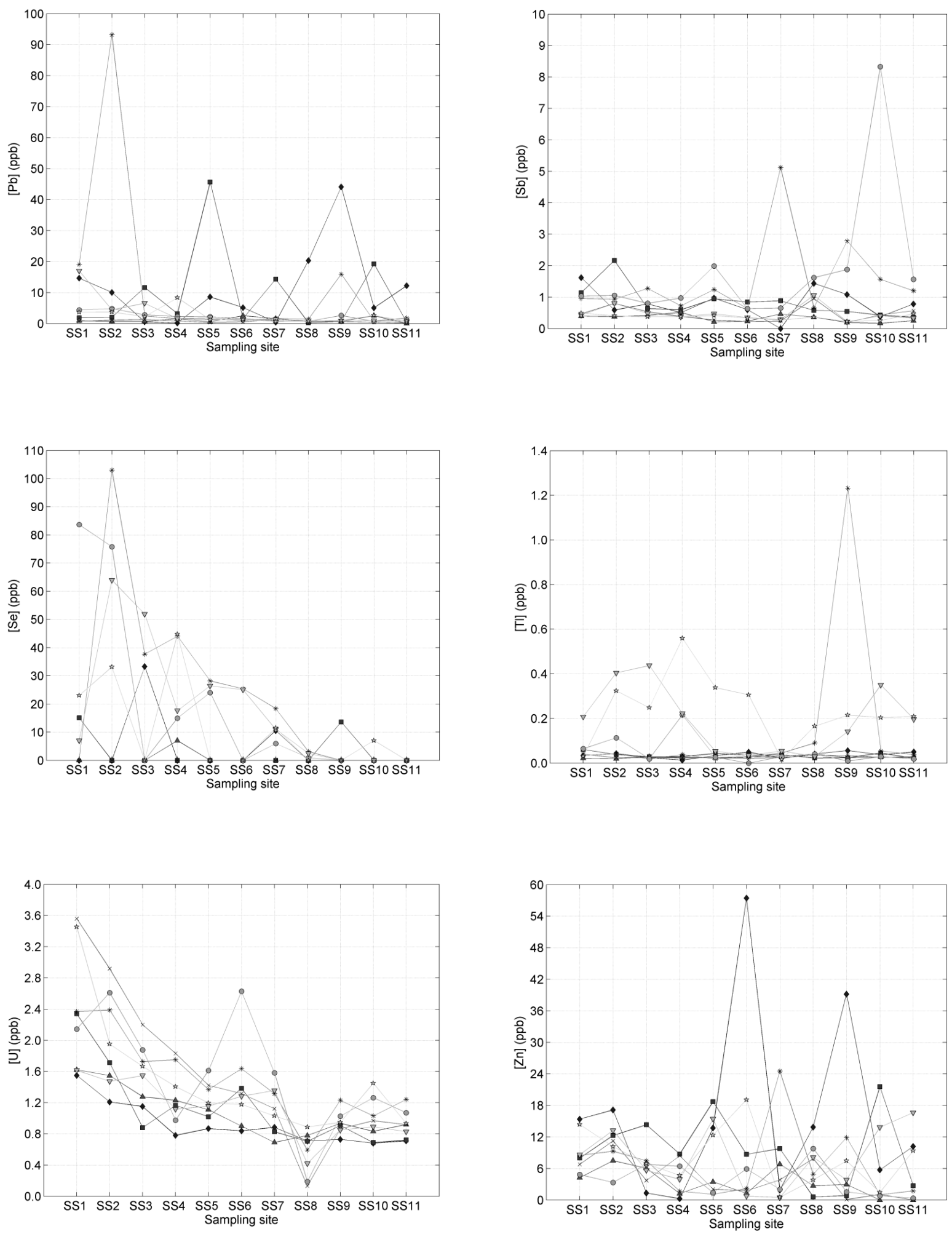

(c)

Figure $\mathbf{3}(\mathbf{a}, \mathbf{b}$ and $\mathbf{c})$. Trace element levels $(\mathrm{ppb})$ at the different 11 sampling sites (mean values for the 8 samples: 4 seasons $x$ two tides). Legend: $\bullet$ October LT; October HT; $\boldsymbol{\Delta}$ January LT; $\times$ January HT; * March LT; $\bigcirc$ March HT; $\nabla$ July LT; $\star$ July HT. 


\subsection{Multivariate data analysis}

Principal component analysis (PCA) is the most widely used method of multivariate data analysis when a dimension reduction is necessary (Naes et al., 2002). The results from a PCA performed in order to unveil correlations among the different water parameters analyzed are presented and discussed in next sections. PCA was applied to both main water physicochemical parameters $(\mathrm{pH}, \mathrm{DO}$ temperature and conductivity) and trace element concentrations. In order to normalize all variables, data were previously auto-scaled before PCA.

\section{a) Main physicochemical parameters}

Results for PCA of the main water physicochemical parameters measured in the 88 river samples are presented in Figure 4a. Seasonal discrimination was achieved by considering first and second principal components (PC1 and PC2), which captured $71.7 \%$ of total variance. PC1 captures the differences in $\mathrm{pH}$ and DO, showing a positive correlation between these two parameters (Araoye, 2009; Makkaveev, 2009). Samples from July presented higher $\mathrm{pH}$ values, while January samples presented lower $\mathrm{pH}$ values. Regarding DO, samples from March had the highest values and October the lowest DO values. On the contrary, these variables ( $\mathrm{pH}$ and $\mathrm{DO})$ were negatively correlated with conductivity and temperature. PC2 captures the variation of these variables. October and January are characterized by both low $\mathrm{pH}$ and DO values, since cold seasons have less sunny periods, which affect photosynthetic rates. Samples from October and July were discriminated from the samples from January and March by their temperature and conductivity values (higher in the first two months).

\section{b) Trace elements}

A PCA was performed for the whole data set (18 trace elements in 88 samples). Results lower than LOD were replaced by zeros. Loading plot for the whole data set, considering a two-component model, retained $40.7 \%$ of the total variance (Figure $4 b$ ).

Some clusters are visible, reflecting some degree of correlation among some trace elements. Particularly, trace elements such as $\mathrm{Ni}, \mathrm{Zn}$ and $\mathrm{Cu}$ are highly correlated. This correlation was maintained even when only sampling sites not affected by tides were considered (SS8-SS11), reflecting an eventual common source. It is also observed that $\mathrm{Be}, \mathrm{Al}$, and $\mathrm{Mn}$ had a distinct profile from all the other elements, with a tendency for lower values near the river mouth. Some correlation (weaker) seems also to exist between $\mathrm{Cr}$ and $\mathrm{Pb}$ and $\mathrm{Cd}$, Co and Mo. Metals close to the chart origin ( $\mathrm{Sb}, \mathrm{Ag}$ and $\mathrm{Ba}$ ) showed low variability.

The spatial and seasonal distribution of the studied trace elements along the $22 \mathrm{~km}$ of Douro river lower basin was also evaluated using the PCA model. Figure 4c shows the first principal component (PC1) represented according to the distance to the river mouth. A clear relationship could be observed up to SS7, which indicates that the major changes on trace element levels occur within the first $10 \mathrm{~km}$ from the river mouth. From the analysis of loadings on PC1 (Figure 4c), the trace elements which showed a higher systematic tendency for decreasing levels along the river in the upstream direction were $\mathrm{Cr}, \mathrm{Co}$, $\mathrm{Mo}, \mathrm{Cd}$ and $\mathrm{U}$. An inverse tendency was observed for $\mathrm{Be}, \mathrm{Al}$ and $\mathrm{Mn}$.

Regarding seasonal variations, PCA shows a discrimination of October (mainly due to higher levels of $\mathrm{Cu}$, $\mathrm{Zn}$ and $\mathrm{Ni}$ ) and July (mainly due to higher levels of $\mathrm{Co}, \mathrm{Cd}$ and $\mathrm{Mo}$ ) (Figure 4c). January and March were not separated, and showed lower levels of all the analyzed trace elements, except for $\mathrm{Mn}, \mathrm{Al}$ and Be. Figure $4 \mathrm{c}$ also shows that major variations on trace elements concentration occur in July and October. 

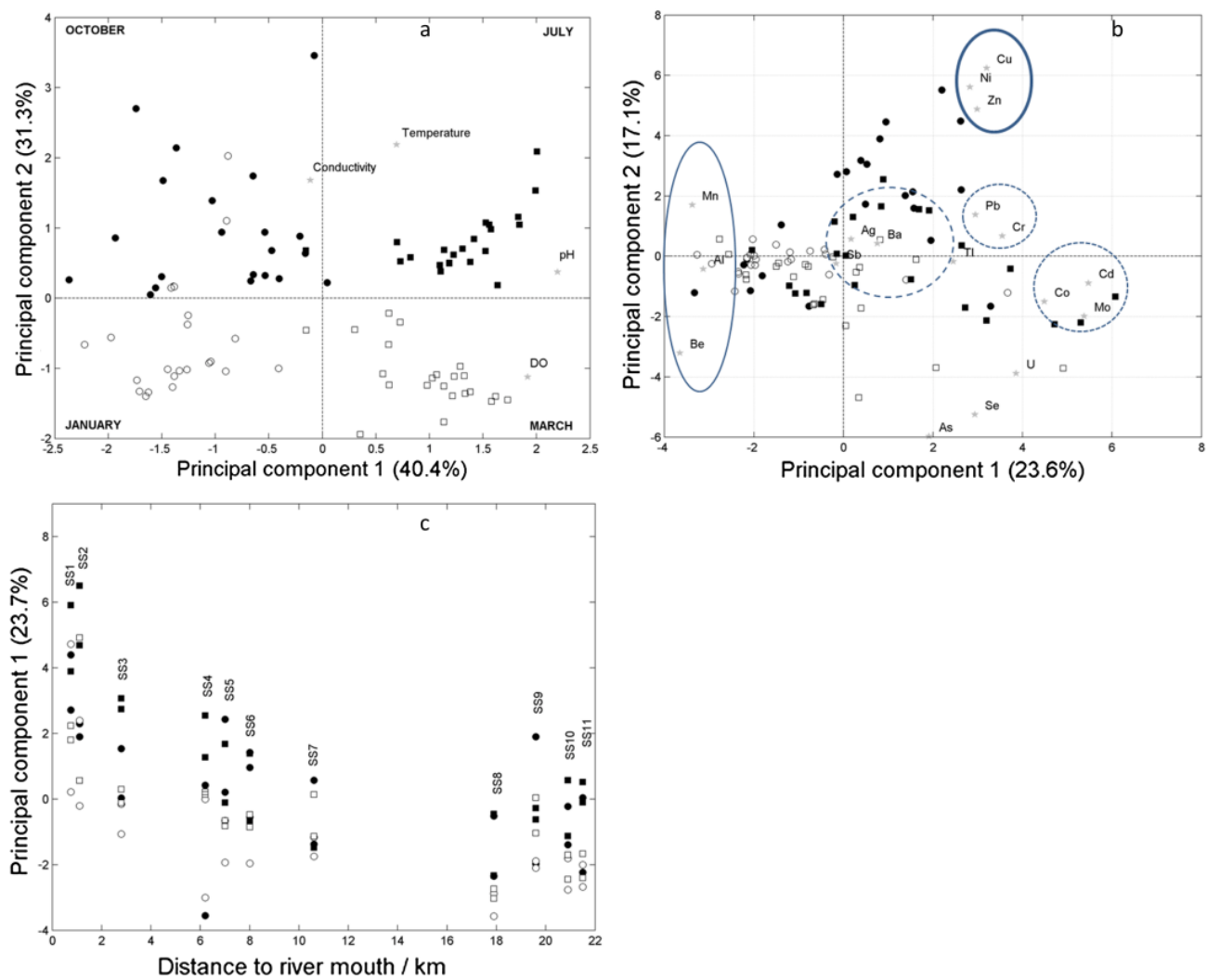

Figure 4 - (a) Principal component 2 versus Principal component 1 for the main physicochemical parameters measured in the 88 Douro River lower basin water samples. Legend: o January; $\square$ March; July; • October. (b) - Representation of Principal component 2 versus Principal component 1 scores and

loadings (biplot) of the PCA model for the 18 trace elements measured on the 88 water samples (4 seasons, 11 sampling sites, in both low and high tide) of the Douro River lower basin. Legend: 0 January scores; $\square$ March scores; $\square$ July scores; $\bullet$ October scores; $\star$ loadings. (c) - Representation of Principal component 1 (of trace element PCA) versus distance to the river mouth. Legend: 0 January; $\square$ March;

- July; • October.

\section{Conclusions}

The Douro River lower basin water quality was studied by analyzing its main physicochemical parameters and trace element levels.

The main conclusions can be summarized as follows:

- Taking as reference the WHO guidelines for drinking water, the quality of Douro River water in this area can be regarded as acceptable except for DO, where a significant number of samples presented levels below $5.0 \mathrm{mg} \mathrm{l}^{-1}$. When we use as reference recommended aquatic life limit criteria for fresh water we can conclude that for most of the elements the mean values found were in accordance to aquatic life limits (except for $\mathrm{Cr}$, Se, $\mathrm{Ag}$ ), but in some of the samples occasional high levels were found for trace elements, reflecting occasional/local inputs into the river (aquatic life limits were exceeded for Al, $\mathrm{Cr}, \mathrm{Zn}, \mathrm{As}$, Se and TI).

- Important spatial differences were observed. It was shown that seawater significantly affects estuarine water composition up to sampling site SS7 (ca. $11 \mathrm{~km}$ from river mouth). Except for a few cases (Be, $\mathrm{Al}$ and $\mathrm{Mn}$ ), typically the trace element levels tended to increase in the downstream direction. This may be a consequence of increased inputs along the basin and/or sediment resuspension (note: samples were directly analyzed, i.e., not filtered). For Mo, the relatively high 
seawater level is an additional factor for this trend. In the middle of the studied area some trace elements related with agriculture (e.g. $\mathrm{Cu}, \mathrm{Ni}$ and $\mathrm{Zn}$ ) were present at higher levels.

- Sampling site SS8 - located at the confluence of Sousa River with Douro River - showed a distinct trace element profile, with significantly higher levels of some trace elements (e.g., Al, $\mathrm{Mn}, \mathrm{Co}$ ) and significantly lower levels of other (e.g., $\mathrm{U}$ and $\mathrm{Cr}$ ). Some trace element also showed an association with WWTPs (e.g., $\mathrm{Cr}$, Sb and Pb).

- Important seasonal differences in trace element levels were also found. For example, October samples were generally characterized by higher $\mathrm{Ni}, \mathrm{Cu}, \mathrm{Zn}$ and $\mathrm{Pb}$ levels.

In order to fully assess Douro lower basin trace element contamination, and to get further information on environmental quality of this important ecosystem, further monitoring studies are in progress, namely on sediments (considered to be active compartments with a playing role in redistribution of metals to biota) and on aquatic organisms, acting as bioindicators of uptake and bioavailability of some heavy metals, and air quality.

\section{Acknowledgment}

This work was supported by the Fundação para a Ciência e a Tecnologia (FCT), Ministério da Ciência, Tecnologia e Ensino Superior (MCTES), under Project PTDC/SAU-ESA/108871/2008, and CESPU, through Project 01-GCQF-CICS09.

\section{References}

Araoye P.A. (2009), The seasonal variation of $\mathrm{pH}$ and dissolved oxygen $\left(\mathrm{DO}_{2}\right)$ concentration in Asa lake llorin, Nigeria, International Journal of Physical Sciences, 4(5), 271-274.

Azevedo I.C., Duarte P.M. and Bordalo A.A. (2006), Pelagic metabolism of the Douro estuary (Portugal) - Factors controlling primary production, Estuarine, Coastal and Shelf Science, 69(1), 133-146.

Barrow C.J. (1998), River basin development planning and management: A critical review, World Development, 26(1), 171-186.

Bettencourt P., Alcobia S., Silva N. (2009), Environmental Impact Assessment of the Douro Jetties: a success case in Proceedings of the 29th Annual Conference of the International Association for Impact Assessment.

Callender E. (2003), Heavy metals in the environment - historical trends. In: Treatise on Geochemistry, vol. 9: Environmental Geochemistry (pp. 67-105). Holland H.D. and Turekian K.K. (Eds.), Elsevier Pergamon, Oxford.

CCME (Canadian Council of Ministers of the Environment), "Canadian Water Quality Guidelines" (1999). Available at: http://st-ts.ccme.ca/. Accessed 19 May 2013.

Censi P., Spoto S.E., Saiano F., Sprovieri M., Mazzola S., Nardone G., Di Geronimo S. I., Punturo R. and Ottonello D. (2006), Heavy metals in coastal water system. A case study from the northwestern Gulf of Thailand, Chemosphere, 64(7), 1167-1176.

Clesceri L.S., Greenberg A.E., Eaton A.D. (1999), Standard Methods for the Examination of Water and Wastewater, Twentieth Edition, DC: American Public Health Association, Washington.

Cornelis R., Caruso J., Crews H., Heumann K. (2005), In: Handbook of Elemental Speciation II: Species in the Environment, Food, Medicine and Occupational Health. John Wiley and Sons, Chichester.

Creed J.T., Brockhoff C.A., Martin T.D. (1994), Method 200.8: Determination of trace elements in waters and wastes by inductively coupled plasma - mass spectrometry, revision 5.4, EMMC version. U.S. Environmental Protection Agency, Cincinnati, $\mathrm{OH}$.

IARC (International Agency for Research on Cancer), (2011), Agents Classified by the IARC Monographs, Volumes 1102. http://monographs..fr/ENG/Classification/ClassificationsAlpha Order.pdf. Accessed 20 June 2011.

INAG (Instituto Nacional da Água), National Water Institute, 2011. Douro description:

http://www.inag.pt/estuarios/MenusEstuarios/Descri\%C3\%A7\% C3\%A3o/descricao_Douro.htm accessed on May 102011.

Lenntech B.V. The chemical elements and water. http://www.lenntech.com/periodic/ water/overview.htm. Accessed 5 May 2011. 
Linde A., Arribas P., Sánchez-Galán S., Marañon E., Izquierdo J., García-Vázquez F. (1995), Preliminary assessment and biological impact of trace metal pollution in Piles river (Spain). In: Water Pollution III: Modelling, Measurement and Prediction (pp. 407-414). Wrobel L.C., Latinopoulos P. (Eds.), Ashurst: Computation Mechanics Publication.

Magalhães C., Joye S., Moreira R., Wiebe W. and Bordalo A. (2005a), Effect of salinity and inorganic nitrogen concentrations on nitrification and denitrification rates in intertidal sediments and rocky biofilms of the Douro River estuary, Portugal, Water Research, 39(9), 1783-1794.

Magalhães C.M., Bordalo A.A. and Wiebe W.J. (2002), Temporal and spatial patterns of intertidal sediment-water nutrient and oxygen fluxes in the Douro River estuary, Portugal, Marine Ecology Progress Series, 233, 55-71.

Magalhães C.M., Bordalo A.A. and Wiebe W.J. (2003), Intertidal biofilms on rocky substratum can play a major role in estuarine carbon and nutrient dynamics, Marine Ecology Progress Series, 258, 275-281.

Magalhães C.M., Wiebe W.J., Joye S.B. and Bordalo A.A. (2005b), Nitrogen cycle dynamics and processes in intertidal rocky biofilms and adjacent sediment of the Douro River estuary (Portugal), Estuaries, 28, 592-607.

Makkaveev P.N. (2009), The features of the correlation between the $\mathrm{pH}$ values and the dissolved oxygen at the Chistaya Balka test area in the Northern Caspian Sea, Oceanology, 49(4), 466-472.

Mendiguchía C., Moreno C. and García-Vargas M. (2007), Evaluation of natural and anthropogenic influences on the Guadalquivir River (Spain) by dissolved heavy metals and nutrients, Chemosphere, 69(10), 1509-1517.

Miller G.G., Sweet L.I., Adams J.V., Omann G.M., Passino-Reader D.R. and Meter P.G. (2002), In vitro toxicity and interactions of environmental contaminants (Arochlor 125 and mercury) and immunomodulatory agents (lipopolysaccharidae and cortisol) on thymocytes from lake trout (Salvelinus namaycus), Fish \& Shellfish Immunology, 13(1), 11-26.

Mucha A.P., Bordalo A.A. and Vasconcelos M.T. (2004), Sediment quality in the Douro River estuary based on trace metal contents, macrobenthic community and elutriate sediment toxicity test (ESTT), Journal of Environmental Monitoring, 6(7), 585-592.

Mucha A.P., Vasconcelos M.T. and Bordalo A.A. (2003), Macrobenthic community in the Douro Estuary: relations with trace metals and natural sediment characteristics, Environmental Pollution, 121(2), 169-180.

Mucha A.P., Vasconcelos M.T. and Bordalo A.A. (2005), Spatial and seasonal variations of the macrobenthic community and metal contamination in the Douro estuary (Portugal), Marine Environmental Research, 60(5), 531-550.

Naes T., Isaksson T., Fearn T., Davis T. (2002), A User-Friendly Guide to Multivariate Calibration and Classification, NIR Publications, Chichester.

Nixon S. Indicator Fact Sheet (WHS2) - Hazardous substances in rivers. http://www.eea.europa.eu/data-andmaps/indicators/hazardous-substances-in-rivers/whs2_hazardoussubstancesrivers_180504.pdf. Accessed 20 May 2011.

SNIRH (Sistema Nacional de Informação de Recursos Hídricos), National Data System of Water Resources. Precipitation Bulletin.

http://snirh.pt/index.php?idMain=1\&idltem=1.1. Accessed 10 May 2011.

Tagami K., Uchida S. (2009), Thorium and uranium concentrations in 44 Japanese river waters - Possible uranium addition from agricultural fields to river waters, In: From Headwaters to the Ocean: Hydrological Change and Water Management - Hydrochange, Fukushima Y., Burnett W.C., Taniguchi M., Haigh M., Umezawa Y. (Eds.). CRC Press, London.

Turekian K. K. (1976), Oceans, Second Edition, Prentice-Hall, New Jersey.

WHO (World Health Organization), (2011), Guidelines for drinking-water quality, Fourth Edition available at http://whqlibdoc.who.int/publications/2011/9789241548151_eng.pdf., Accessed 20 May 2013. 